\title{
FUN BOSS GAMES: Literasi Investor Menuju Indonesia Sebagai Pusat Pasar Modal Syariah
}

\author{
Indah Maesaroh \\ Universitas Islam Negeri (UIN) Sunan Kalijaga \\ Email : imaezyaroh@hmail.com
}

\begin{abstract}
The existence of the capital market among the financial industry in Indonesia has not triggered the attractiveness of the people to become investors. The 2016 Financial Services Authority (OJK) publication stated that the capital market literacy index declined from $0.02 \%$ in 2013 to $0.01 \%$ in 2016. In addition, its position was below the banking industry (9.61\%), insurance (1, 92\%), pawnshops (0.71\%), and financial institutions $(0.24 \%)$. Therefore, through conceptual research with a qualitative approach to literature review it is intended to offer the concept of financial literacy in the Islamic capital market. Researchers offer interesting and fun literacy models in the Islamic capital market through "fun boss games". Fun Boss Games is a game with players of an investor who invests in sharia capital market products both in the short term (to gain world profits) and in the long term (to gain afterlife benefits). The challenges in these games are divided into four stages to become winning investors, namely the first stage for investors not literate, the second stage for investors is less literate, the third stage is suft literate, and the fourth stage is well literate. The subject will be offered with several investment products along with the risks both in the long term and in the short term according to the stages being achieved. Thus, investors must get a high point to go up the next stage. This game literacy model is in accordance with the character of investors who like the business challenges of investing in the Islamic capital market because they have long-term (afterlife) considerations. The implementation of fun boss games has become a literacy material for potential investors before facing the challenges of investment in the actual Islamic capital market. Thus, the concept of this game is able to reduce the investment risk of the Islamic capital market due to a lack of understanding of investors. In the long term, it is expected to be able to create smart investors who are ready to invest towards the center of the Islamic capital market in Indonesia.
\end{abstract}

\section{Keywords: Sharia Capital Market, Investor Literacy, Fun Boss Games}

\begin{abstract}
Abstrak
Keberadaan pasar modal dikalangan industri keuangan di Indonesia kurang memicu daya tarik masyarakat untuk menjadi investor. Publikasi Otoritas jasa Keuangan (OJK) tahun 2016 menyatakan bahwa indeks literasi pasar modal menurun dari $0,02 \%$ pada tahun 2013 menjadi 0,01\% pada tahun 2016. Selain itu, kedudukanya dibawah industri perbankan (9,61\%), perasuransian $(1,92 \%)$, pegadaian $(0,71 \%)$, dan lembaga pembiayaan $(0,24 \%)$. Oleh sebab itu, melalui penelitian yang dilakukan secara konseptual dengan pendekatan kualitatif pada telaah literatur ini ditujukan untuk menawarkan konsep literasi keuangan pada pasar modal syariah. Peneliti menawarkan model literasi yang menarik dan menyenangkan dalam pasar modal syariah melalui "fun boss games". Fun Boss Games merupakan permainan dengan pemain seorang investor yang berinvestasi pada produk-produk pasar modal syariah baik dalam jangka pendek (untuk mendapatkan keuntungan dunia) maupun dalam jangka panjang (untuk mendapatkan keuntungan akhirat). Tantangan dalam games ini dibagi dalam empat tahapan untuk menjadi investor pemenang yakni tahap pertama bagi investor not literate, tahap kedua bagi investor less literate, tahap ketiga suft literate, dan tahap keempat well literate. Subjek akan ditawarkan dengan beberapa produk investasi beserta risikonya baik dalam jangka panjang maupun jangka pendek
\end{abstract}


sesuai tahapan yang sedang dicapai. Dengan demikian, investor harus mendapatkan point yang tinggi untuk naik ketahap selanjutnya. Model literasi permainan ini sesuai dengan karakter investor yang menyukai tantangan bisnis dalam berinvestasi di pasar modal syariah karena memiliki pertimbangan hingga jangka panjang (akhirat). Implementasi atas fun boss games ini menjadi bahan literasi calon investor sebelum menghadapi tantangan investasi pada pasar modal syariah yang sebenarnya. Dengan demikian, konsep permainan ini mampu mengurangi risiko investasi pasar modal syariah karena kurangnya pemahaman investor. Dalam jangka panjang, diharapkan mampu menciptakan para investor- investor cerdas yang siap melakukan investasi menuju pusat pasar modal syariah di Indonesia.

\section{Keywords: Pasar Modal Syariah, Literasi Investor, Fun Boss Games}

\section{Pendahuluan}

Pasar modal memiliki peran yang besar bagi perekonomian suatu Negara, dikarenakan pasar modal memiliki dua fungsi sekaligus, yaitu fungsi ekonomi dan fungsi keuangan. Pasar modal memiliki fungsi ekonomi karena pasar modal menyediakan sarana atau fasilitas yang mempertemukan dua pihak, yaitu pihak yang memiliki kelebihan dana (investor) dan pihak yang memerlukan dana (issuer). Pasar modal dikatakan memiliki fungsi keuangan, dikarenakan pasar modal memberikan kesempatan bagi pemilik dana memperoleh imbalan (return) sesuai dengan karakteristik investasi yang dipilih (Soemitra, 2009).

Jika dilihat dari tahun 2010 pertumbuhan perekonomian Indonesia mengalami penurunan dari tahun ke tahun, oleh karena itu pasar modal di harapkan mampu menguatkan perekonomian Indonesia saat ini. Tahun 2015 adalah tahun dimana melambatnya perekonomian dunia, namun di tengah melambatnya perekonomian dunia, perekonomian Indonesia masih dapat tumbuh sebesar $(4,79 \%)$.

Sumber : Badan Pusat Statistik (BPS)

Gambar 1. Pertumbuhan Ekonomi Indonesia, Tahun 2010 - 2016

Dengan stabilitas makro ekonomi yang tetap terjaga perekonomian Indonesia menunujukan perkembagan yang positif hinga enam bulan pertama di tahun 2016. Ekonomi

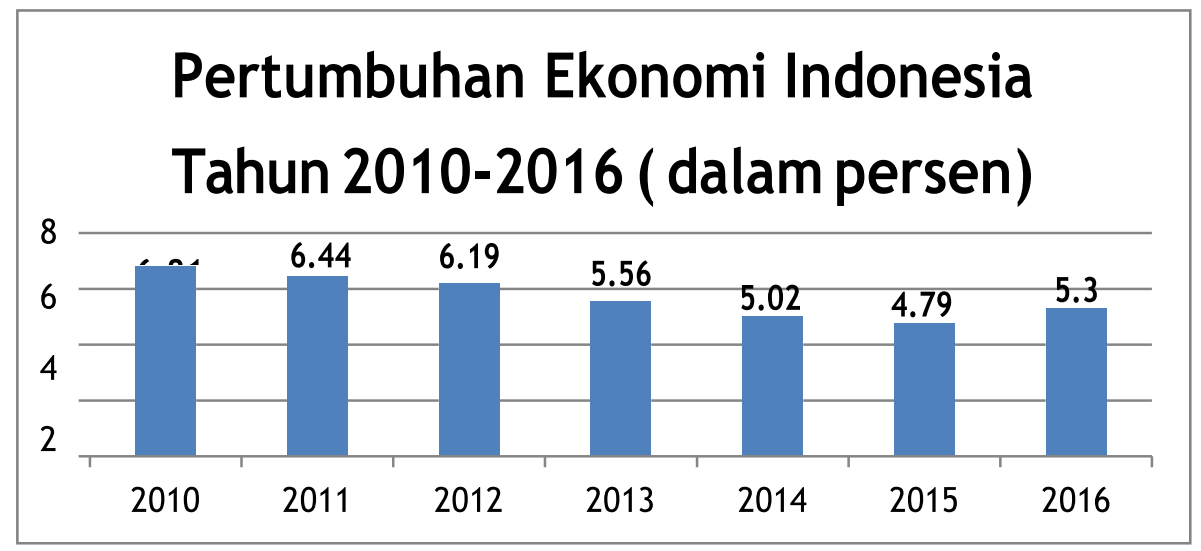

Indonesia tahun 2016 tumbuh sebesar 5,3\%, lebih tinggi dibandingkan periode yang sama pada tahun sebelumnya yakni sebesar 4,79\%. Hal ini menunjukan bahwa prospek ekonomi Indonesia kedepannya masih cukup positif dan diharapkan dengan upaya keras pemerintah dan masyarakat, ekonomi Indonesia pada awal tahun 2017 di perkirakan dapat tumbuh sebesar 5,36\% (Kompas.com). 
Berdasarkan data dari Otoritas Jasa Keuangan (OJK), menunjukan bahwa pengguna atau investor yang paling rendah adalah pengguna (investor) di pasar modal yaitu sebesar $(0.11 \%)$ pada tahun 2013 dan (1.25\%) pada tahun 2016. Untuk mengetahui perbandingan pengguna pasar modal dengan instrument keuangan lainya, bisa di lihat dari data inklusi keuangan.

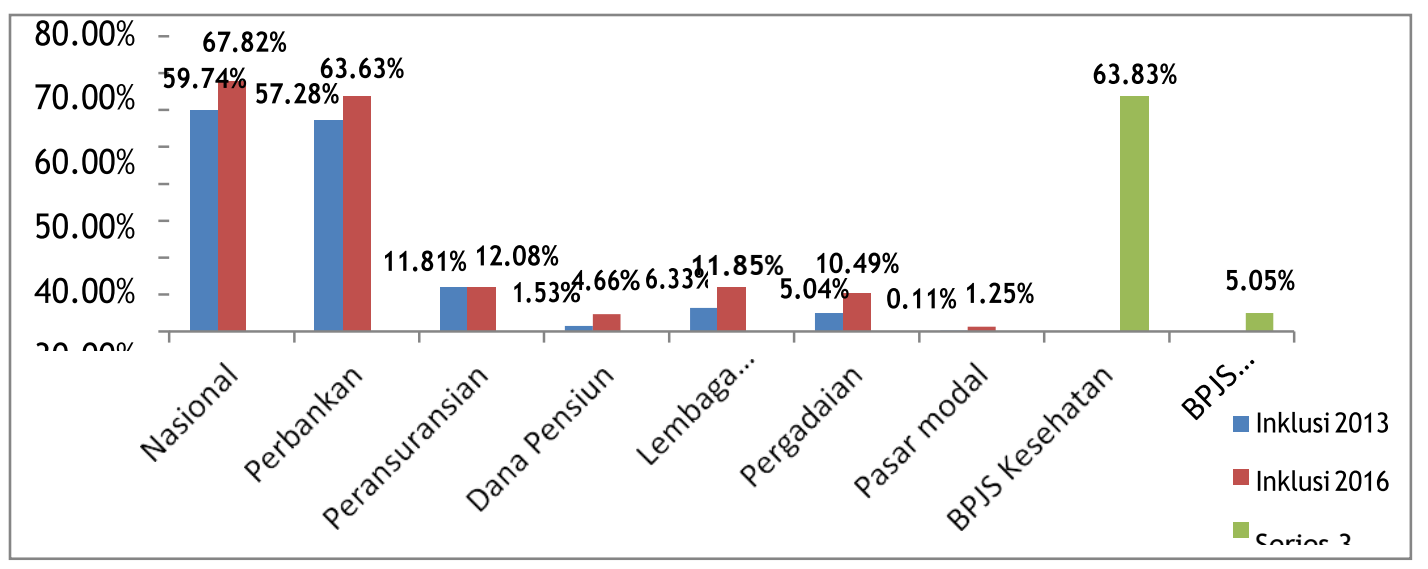

Sumber : Otoritas Jasa keuangan 2016

Gambar 2. Indeks inklusi keuangan - sektoral ( 2013 - 2016)

Dari grafik diatas bisa kita lihat bahwa pengguna pasar modal Indonesia masih sangat sedikit dibandingkan dengan pengguna instrument keuangan lainya. Jika dibandingkan dengan pengguna perbankan yang mencapai (57.28\%) pada tahun 2013 dan (63.63\%) pada tahun 2016, pengguna pasar modal masih sangat sedikit atau masih sangat rendah yaitu sebesar $(0.11 \%)$ pada tahun 2013 dan (1.25\%) pada tahun 2016, bukan hanya dibandingkan dengan perbankan saja, jika dilihat dari grafik diatas pengguna pasar modal adalah pengguna yang paling rendah dibandingkan dengan instrument keuangan yang lainya.

Hal ini sebanding dengan data indeks literasi keuangan sektoral Indonesia. Dari data indeks literasi keuangan menyatakan bahwa indeks literasi instrument keuangan (perbankan, peransuransian, pergadaian, dan lain- lain) lebih tinggi daripada literasi pasar modal. 
Sumber: Otoritas Jasa Keuangan (2016)

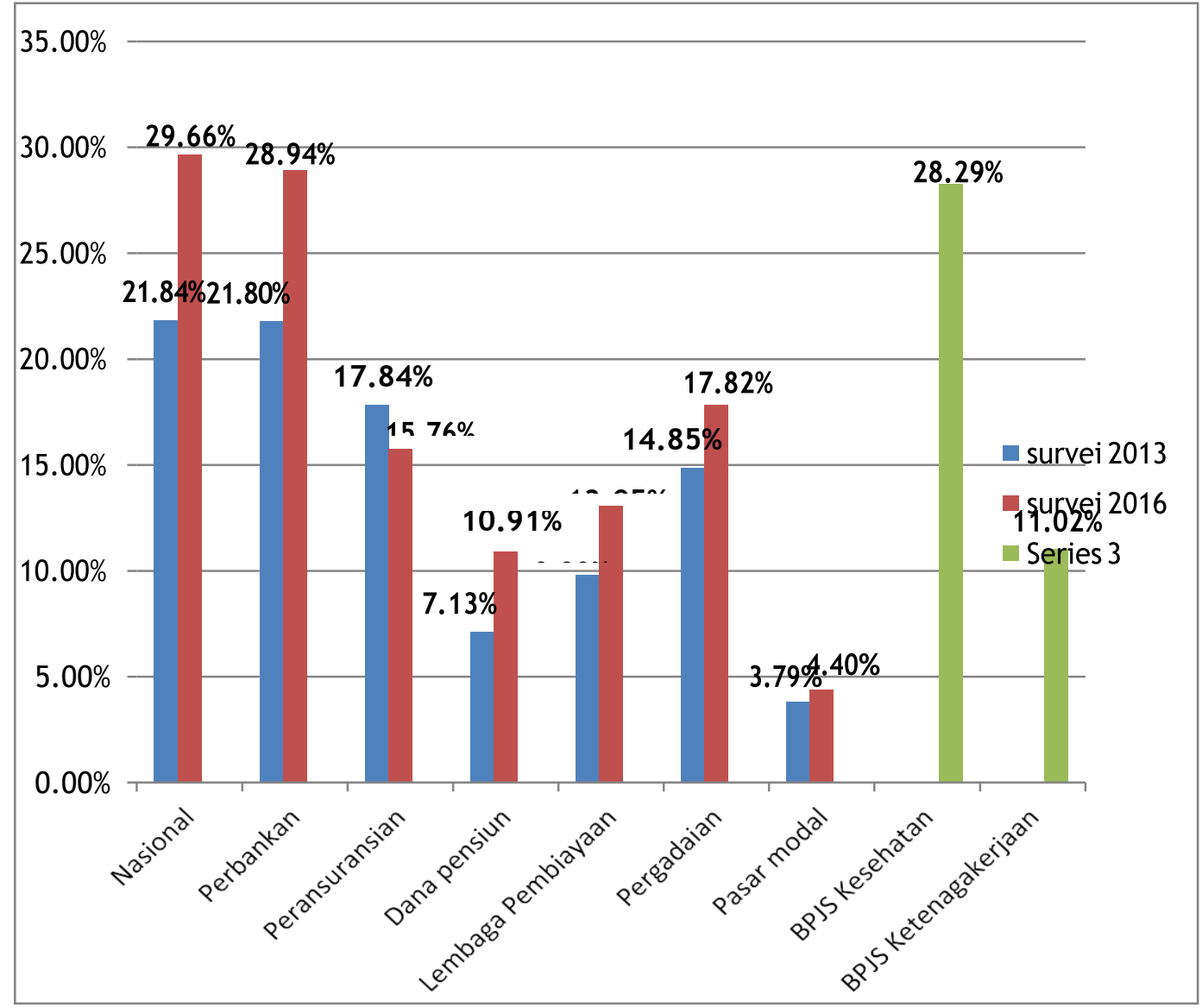

Gambar 3. Indeks Literasi Keuangan - Sektoral ( 2013 - 2016 )

Dari grafik diatas dapat dilihat bahwa pasar modal memiliki indeks literasi yang paling rendah dibandingkan instrument keuangan yang lainya. Literasi keuangan sendiri dapat diartikan sebagai kecakapan atau kesanggupan dalam hal keuangan. Jika kita lihat dari dua grafik diatas, grafik inklusi (pengguna) sebanding dengan grafik literasi (kecakapan atau kesanggupan dalam hal keuangan). Bisa kita lihat pada iklusi dan literasi keuangan tahun 2016, indeks inklusi pasar modal sebesar (1.25\%), dan indeks literasi nya sebesar (4.40\%), dari data tersebut bisa kita lihat bahwa kecakapan atau kesanggupan masyarakat dalam hal keuangan itu mempengaruhi pada banyak nya pengguna atau nasabah pada instrument keuangan tersebut.

Dilihat dari data tersebut pasar modal memiliki indeks inklusi dan literasi yang paling rendah dibandingkan instrument keuangan yang lainya, semisal jika di bandingkan dengan perbankan yang memiliki indeks inklusi dan literasi yang paling tinngi, selisih indeks inklusi (pengguna) pasar modal dan perbankan pada tahun 2016 adalah (62.38\%) selisih yang cukup jauh antara inklusi (pengguna) perbankan dan pasar modal, sedangkan selisih litersi perbankan dan pasar modal adalah (24.54\%), hal tersebut menunjukan bahwa kesanggupan dan kecakapan masyarakat Indonesia mengenai pasar modal masih rendah, dan mempengaruh pada jumlah pengguna (investor) pasar modal itu sendiri. Hal itu bisa disebabkan oleh berbagai faktor, salah satu nya adalah masih kurang nya pengetahuan tentang pasar modal di kalangan masyarakat umum, serta paradigma masyarakat bahwa kegiatan pasar modal adalah kegiatan masyarakat kalangan atas, dan memerlukan banyak sekali dana. 
Penerapan prinsip syariah di pasar modal tentunya bersumberkan pada Al Quran sebagai sumber hukum tertinggi dan Hadits Nabi Muhammad SAW. Selanjutnya, dari kedua sumber hukum tersebut para ulama melakukan penafsiran yang kemudian disebut ilmu fiqih. Salah satu pembahasan dalam ilmu fiqih adalah pembahasan tentang muamalah, yaitu hubungan diantara sesama manusia terkait perniagaan. Berdasarkan itulah kegiatan pasar modal syariah dikembangkan dengan basis fiqih muamalah.Terdapat kaidah fiqih muamalah yang menyatakan bahwa "Pada dasarnya, semua bentuk muamalah boleh dilakukan kecuali ada dalil yang mengharamkannya." Konsep inilah yang menjadi prinsip pasar modal syariah di Indonesia (Sutedi, 2011).

Islam mendorong aktivitas investasi sebagai sarana untuk mengembangkan modal atau harta. Investasi merupakan satukesatuan yang berhubungan kuat dengan syariat, hukum Islam bahkan filsafat. Maksud dari investasi di pasar modal syariah adalah menanam modal dengan tujuan menambah keuntungan dan mencari kelebihan nikmat Allah, karena investasi ini akan merealisasikan tujuan permodalan yang seharusnya berkembang, serta tujuan sosial (Sutedi, 2011).

Selain landasan di atas, terdapat pula hadis Nabi yang berisi, bahwa Rasulullah sendiri tidak setuju membiarkan sumber daya modal tidak produktif dengan mengatakan: "Berikanlah kesempatan kepada mereka yang memiliki tanah untuk memanfaatkannya, dengan caranya sendiri dan jika tidak dilakukannya, hendaklah diberikan pula orang lain agar memanfaatkannya" (HR Muslim). Selain itu khalifah Umar R.A menekankan agar umat Islam menggunakan modal mereka secara produktif dengan mengatakan : "Mereka yang mempunyai uang perlu mengivestasikannya, dan mereka yang mempunyai tanah perlu mengeluarkannya". Dalam Islam investasi merupakan kegiatan muamalah yang sangat dianjurkan, karena dengan berinvestasi harta yang dimiliki menjadi produktif dan bermanfaat bagi orang lain (Sutedi, 2011).

Dari pemaparan diatas bisa kita lihat bahwa pasar modal syariah adalah kegiatan investasi yang sesuai dengan prinsip-prinsip syariah dan bertujuan untuk kemaslahatan umat (masyarakat), bukan hanya untuk mengejar keuntungan belaka, namun lebih berorientasi kepada kesuksesan dunia dan akhirat.

Pasar modal syariah Indonesia pada saat ini masih berada pada tahap perkembangan, namun eksistensi pasar modal syariah sendiri masih belum begitu eksis di bandingkan dengan pasar modal konvensional. Hal ini di buktikan dengan data inklusi (pengguna) dan data literasi keuangan pasar modal syariah tahun 2016.

Sumber : Otoritas jasa keuangan

Gambar 4. Perbandingan indeks literasi-inklusi keuangan- sektoral syariah dan konvensional ( 2016 )

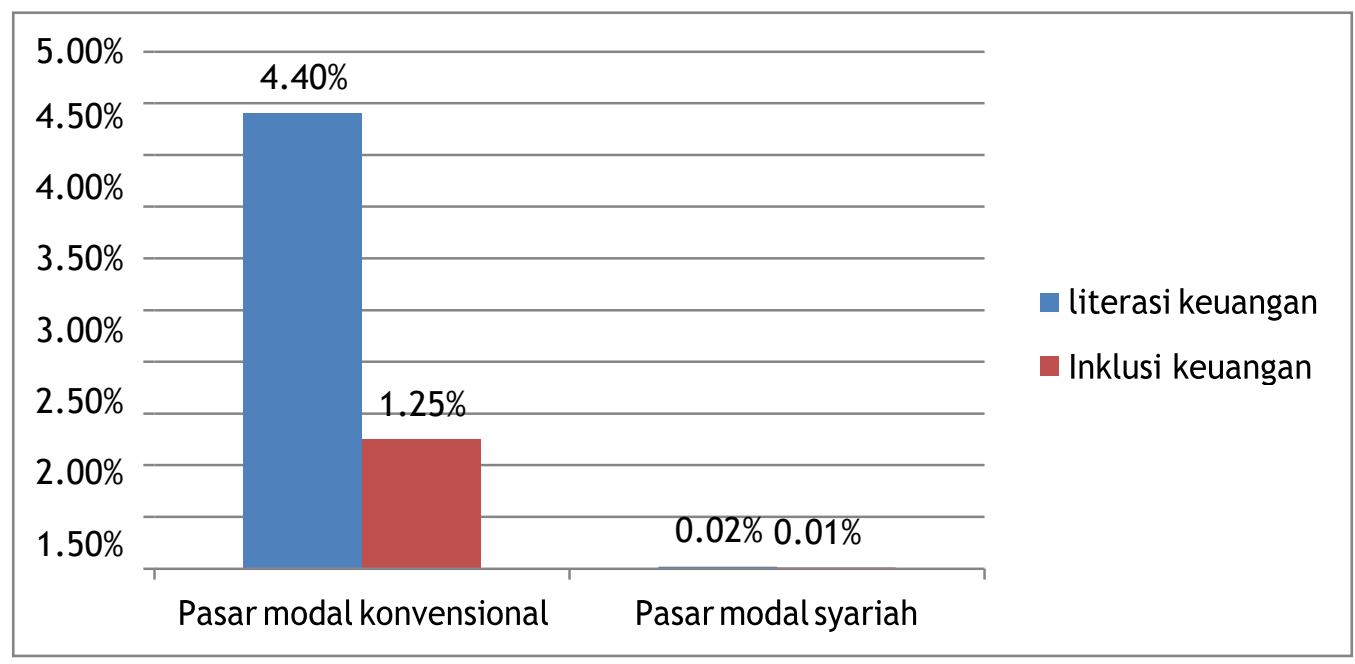


Dari grafik di atas bisa kita lihat bahwa perbandingan antara literasi keuangan pasar modal syariah dengan pasar modal konvensional memiliki jarak atau perbandingan yang cukup jauh, yaitu dengan literasi keuangan pasar modal konvensional sebesar $4.40 \%$ sedangkan pasar modal syariah hanya sebesar $0.02 \%$. Begitu juga dengan indeks inklusi keuangan pasar modal konvensional sebesar $1.25 \%$ sendangkan indeks inklusi pasar modal syariah sebesar $0.01 \%$.

Oleh sebab itu, melalui penelitian yang dilakukan secara konseptual dengan pendekatan kualitatif pada telaah literatur ini ditujukan untuk menawarkan konsep literasi keuangan pada pasar modal syariah. Peneliti menawarkan model literasi yang menarik dan menyenangkan dalam pasar modal syariah melalui "Fun Boss Games".

Fun Boss Games merupakan permainan dengan pemain seorang investor yang berinvestasi pada produk-produk pasar modal syariah baik dalam jangka pendek (untuk mendapatkan keuntungan dunia) maupun dalam jangka panjang (untuk mendapatkan keuntungan akhirat). Tantangan dalam games ini dibagi dalam empat tahapan untuk menjadi investor pemenang yakni tahap pertama bagi investor not literate, tahap kedua bagi investor less literate, tahap ketiga suft literate, dan tahap keempat well literate. Subjek akan ditawarkan dengan beberapa produk investasi beserta risikonya baik dalam jangka panjang maupun jangka pendek sesuai tahapan yang sedang dicapai. Dengan demikian, investor harus mendapatkan point yang tinggi untuk naik ketahap selanjutnya.

Model literasi permainan ini sesuai dengan karakter investor yang menyukai tantangan bisnis dalam berinvestasi di pasar modal syariah karena memiliki pertimbangan hingga jangka panjang (akhirat). Implementasi atas fun boss games ini menjadi bahan literasi calon investor sebelum menghadapi tantangan investasi pada pasar modal syariah yang sebenarnya. Dengan demikian, konsep permainan ini mampu mengurangi risiko investasi pasar modal syariah karena kurangnya pemahaman investor. Dalam jangka panjang, diharapkan mampu menciptakan para investor-investor cerdas yang siap melakukan investasi menuju pusat pasar modal syariah di Indonesia. Adapun rumusan masalah dalam karya tulis ilmiah ini meliputi: Inovasi, proses, teknis dan kontribusi akhir atas pengimplementasi literasi pasar modal syariah melalui game.

\section{Tahapan Literasi Produk Atau Instrumen Keuangan Syariah}

Menurut lembaga Otoritas Jasa Keuangan (2013) bahwa secara definisi literasi diartikan sebagai kemampuan memahami. Jadi literasi keuangan adalah kemampuan mengelola dana yang dimiliki agar berkembang dan hidup bisa lebih sejahtera dimasa yang akan datang. OJK mengatakan bahwa hal penting dari program literasi keuangan adalah untuk melakukan edukasi di bidang keuangan kepada masyarakat agar dapat mengelola keuangan secara pintar, agar rendahnya pengetahuan akan industri keuangan dapat diatasi dan masyarakat tidak akan mudah tertipu terhadap investasi- investasi bodong.

Literasi keuangan juga merupakan perangkat penentu utama dalam mewujudkan keuangan inklusi yang mana tahapan ini mengandung muatan- muatan pengenalan basic knowledge dan basic skill dalam memahami sektor keuangan. Tahap literasi ini penting dalam sektor keuangan, tanpa bisa memahami karakteristik produk dan profil risiko keuangan, dapat menyebabkan potensi menjadi korban transaksi keuangan.

Aktivitas yang paling penting dalam tahapan ini adalah sosialisasi dan edukasi secara aktif terkait jenis, karakter, dan profil risiko masing-masing produk keuangan serta dasar-dasar pengelolaan keuangan yang baik. Literasi tidak akan tercapai hanya dengan membangun 
kesadaran terhadap sektor keuangan saja melainkan harus ada program penunjang literasi tersebut. dalam hal ini terdapat empat tahapan dalam literasi keuangan yaitu literacy,, penetration, density, dan delivery.

Literacy merupakan perangkat utama dalam mewujudkan financial inclusion, tahapan ini mengandung muatan pengenalan basic knowledge dan basic skill dalam memahami sektor keuangan dengan program yang dijalankan seperti edukasi dan kampanye nasional yang di lakukan oleh OJK (Otoritas Jasa Keuangan) hal ini sejalan dengan salah satu tujuan Otoritas Jasa Keuangan sesuai dengan Undang-Undang Otoritas Jasa Keuangan No. 21 Tahun 2011 tentang Otoritas Jasa Keuangan yang memberikan amanat kepada Otoritas Jasa Keuangan untuk melakukan edukasi dan perlindungan konsumen dan masyarakat.

OJK (Otoritas Jasa Keuangan) melaksanakan program literasi keuangan dengan tujuan agar masyarakat bukan hanya menjadi well literate dalam masalah keuangan, melainkan juga menggunakan produk dan jasa keuangan untuk memenuhi kebutuhan keuangan mereka sebagai salah satu bentuk implementasi.

Edukasi dan kampanye yang dilakukan oleh OJK (Otoritas Jasa Keuangan) dilakukan dengan menyusun program edukasi dan kampanye nasional literasi keuangan, melaksanakan edukasi dan kampanye nasional literasi keuangan.

a. Penetration merupakan tahapan lanjutan dalam mewujudkan literasi keuangan, dalam tahap ini masyarakat sudah memiliki kesadaran tentang kebutuhan layanan keuangan.34 Kebutuhan paling penting dalam tahap ini adalah supply side layanan keuangan, baik yang berupa produk maupun infrastruktur layanan keuangan baik berupa produk maupun infrastruktur layanan seperti kantor, agen, teknologi informasi. Dalam program strategi yang di lakukan OJK (Otoritas Jasa Keuangan) bekerjasama dengan Industri Jasa Keuangan melaksanakan program seperti kuliah umum, training of trainer, edu expo.

b. Density merupakan tahap di mana kondisi masyarakat sebagai konsumen dan lembaga jasa keuangan sebagai produsen sudah berada dalam kondisi memenuhi syarat untuk membangun jalinan kerjasama. Dalam tahap ini yang paling penting adalah adanya desain produk dan layanan keuangan yang menarik dan dapat diterima di pasar.

c. Delivery merupakan tahap dimana literasi keuangan dan financial inclusion sudah terjadi, ditandai dengan fakta bahwa produk dan layanan keuangan yang dapat diterima dengan baik oleh pasar. Pada tahap ini kebutuhan yang paling penting adalah lembaga keuangan harus memilih jalur distribusi (delivery channel) yang dekat, mudah dijangkau oleh rakyat kecil, dan murah.

\section{Dasar-Dasar Atau Urgensi Pasar Modal Syariah}

Pasar Modal berdasarkan Undang-undang Nomor 8 Tahun 1995 Tentang Pasar Modal dalam Bab I Ketentuan Umum, Pasal 1 ayat (13), yang didalamnya disebutkan bahwa Pasar Modal adalah kegiatan yang bersangkutan dengan Penawaran Umum dan perdagangan Efek, Perusahaan Publik yang berkaitan dengan Efek yang diterbitkannya, serta lembaga dan profesi yang berkaitan dengan Efek.

Pasar modal Syariah secara sederhana diartikan sebagai pasar modal yang menerapkan prinsip-prinsip syariah dalam kegiatan transaksi ekonomi dan terlepas dari hal-hal yang dilarang seperti: riba, perjudian, spekulasi. Dasar hukum Pasar Modal Syarie ah dijelaskan dalam Al-Qur an surat Al- Baqarah ayat 279, An-Nisae ayat 29, Al-Jumu ee ah ayat 10, Al-Maidah ayat 1 dan surat Al- 
Baqarah ayat 278, Allah berfirman:

"Hai orang-orang yang beriman, bertakwalah kepada Allah dan tinggalkan sisa Riba (yang belum dipungut) jika kamu orang-orang yang beriman" (Q.S Al-Baqarah :278) (Jusmaliani, 2008: 34)

Selain UU No. 8 tahun 1995 tentang pasar modal yang menjadi landasan hukum pasar modal syariah, terdapat juga Undang-Undang yang mengatur tentang SBSN (Surat Berharga Syariah Negara), yaitu UU No. 19 Tahun 2008 tentang Surat Berharga Syariah Negara.

\section{Praktik Atau Mekanisme Tahapan Penggunaan Pasar Modal Syariah}

Instrumen pasar modal yang bersifat kepemilikan diwujudkan dalam bentuk saham, sedangkan yang bersifat hutang diwujudkan dalam obligasi. Instrumen pasar modal pada prinsipnya adalah semua surat-surat berharga (efek) yang diperdagangkan di bursa, karena itu bentuknya beraneka ragam. Instrumen yang boleh diperjualbelikan dalam pasar modal syariah hanya apabila memenuhi kriteria syariah. Untuk memastikan bahwa instrumen tersebut benarbenar sesuai dengan prinsip syariah, maka perlu dilakukan konversi melalui proses screening terhadap kegiatan pasar modal. Adapun yang menjadi instrumen pasar modal syariah adalah yang telah dijelaskan di atas (Aziz, 2010: 84-138):

1) Saham Syariah

Saham merupakan instrumen penyertaan modal seseorang atau lembaga dalam suatu perusahaan. Modal ini terbagi dalam tiga tingkat status, yaitu modal dasar, modal ditempatkan, dan modal disetor. Pada dasarnya tidak terdapat pembedaan antara saham yang syariah dengan yang non syariah. Namun saham sebagai bukti kepemilikan suatu perusahaan, dapat dibedakan menurut kegiatan usaha dan tujuan pembelian saham tersebut. Saham menjadi halal (sesuai syariah) jika saham tersebut dikeluarkan oleh perusahaan yang kegiatan usahanya bergerak di bidang yang halal dan/atau dalam niat pembelian saham tersebut adalah untuk investasi, bukan untuk spekulasi. Untuk lebih amannya, saham yang di-listing dalam Jakarta Islamic Index (JII) merupakan saham-saham yang insya Allah sesuai syariah.

2) Obligasi Syariah (Sukuk)

Instrumen pasar modal selain diwujudkan dalam bentuk saham, juga dapat diwujudkan dalam bentuk obligasi. Pada praktiknya sukuk secara umum diidentikkan sebagai "obligasi" yang penerapannya sesuai dengan prinsip-prinsip syariah. Menurut Fatwa DSN-MUI No: 32/DSN- MUI/IX/2002, pengertian obligasi syariah adalah suatu surat berharga jangka panjang berdasarkan prinsip syariah yang dikeluarkan oleh emiten kepada pemegang obligasi syariah yang mewajibkan emiten untuk membayar pendapatan kepada pemegang obligasi syariah berupa bagi hasil/margin/fee serta membayar dana obligasi pada saat jatuh tempo.

3) Reksa dana syariah

Menurut Fatwa No. 20/DSN-MUI/IV/2001, reksa dana syariah adalah reksa dana yang beroperasi menurut ketentuan dan prinsip-prinsip syariah Islam, baik dalam bentuk akad antara pemodal sebagai pemilik shahibu al-maal/rabbu al-maal) dengan manajer investasi sebagai wakil shahibu al-maal, maupun antara manajer investasi sebagai wakil shahibu al-maal dengan pengguna investasi Reksa dana syariah telah beroperasi di industri reksa dana Indonesia. Reksa dana syariah merupakan reksa dana yang berbasiskan prinsip syariah.

\section{Tahap Pembentukan Game}

Menurut Raka (2014), definisi game menurut para ahli adalah sebagai berikut:

"Samuel Hendry, Game merupakan bagian tak terpisahkan dari keseharian anak, sedangkan 
sebagian orang tua menuding game sebagai penyebab nilai anak turun, anak tak mampu bersosialisasi, dan tindakan kekerasan yang dilakukan anak. John Naisbitt, Game merupakan sistem partisipatoris dinamis karena game memiliki tingkat penceritaan yang tidak dimiliki film. Jadi dapat disimpulkan bahwa game adalah suatu aplikasi yang terbentuk hiburan yang dikembangkan sesuai dengan perkembangan zaman saat ini. "

Game atau permainan mempunyai beberapa kelebihan, yaitu: permainan adalah sesuatu yang menyenangkan untuk dilakukan, sesuatu yang menghibur dan menarik. Permainan memungkinkan adanya partisipasi aktif dari siswa untuk belajar. Permainan dapat memberikan umpan balik langsung. Permainan memungkinkan siswa untuk memecahkan masalah- masalah yang nyata. Permainan memberikan pengalaman-pengalaman nyata dan dapat diulangi sebanyak yang dikehendaki, kesalahan-kesalahan operasional dapat diperbaiki. Membantu siswa meningkatkan kemampuan komunikatifnya. Membantu siswa yang sulit belajar dengan metode tradisional. Permainan besifat luwes, dapat dipakai untuk bernagai tujuan pendidikan. Permainan dapat dengan mudah dibuat dan diperbanyak. (Sadiman, Arif. 2006). Berikut merupakan tahaptahap membuat game menurut Wicak (2013), yaitu:

1) Tahap Riset dan Penyusunan Konsep Dasar

Pada tahap ini ide dasar, objektif, tema, target audience, teknologi, media (platform), serta berbagai batasan lain dirumuskan. Tahapan riset ini menjadi sebuah tahapan krusial, berbagai elemen dasar dari sebuah game disusun di sini.

\section{2) Perumusan Gameplay}

Pada tahap ini para game designer merumuskan gameplay/gamechanic yang akan digunakan dalam sebuah game. Gameplay adalah pola, aturan, atau mekanisme yang mengatur bagaimana proses interaksi pemain dengan game yang diciptakan. Gameplay ini juga mengatur bagaimana seorang pemain bisa memenuhi objektif dari game dan mendapatkan pengalaman bermain yang menyenangkan.

3) Penyusunan Asset dan Level Design

Tahapan ini fokus pada penyusunan konsep dari semua karakter serta asset (termasuk suara/musik) yang diperlukan. Pada saat yang sama tim juga mulai melakukan level design atau pengelompokkan tingkat kesulitan serta berbagai asset yang tepat pada tiap level (jika ada lebih dari 1 level) agar game tersebut bisa menghadirkan pengalaman bermain yang optimal.

4) Test Play (Prototyping)

Pada tahapan ini sebuah prototype/dummy dihadirkan untuk menguji gameplay serta berbagai konsep yang telah tersusun, baik dalam tiap level maupun secara keseluruhan, serta melakukan berbagai perbaikan yang diperlukan. Tahapan ini juga berfungsi untuk memberikan gambaran lengkap bagi seluruh tim, sehingga bisa memudahkan proses pengembangan selanjutnya.

5) Development

Pada tahap ini seluruh konsep (karakter dan asset) yang sebelumnya telah tersusun mulai dikembangkan secara penuh, game engine mulai dikembangkan, dan semua elemen mulai dipadukan.

6) Alpha/close beta Test (UX - Initial Balancing)

Fokus utama pada tahap ini adalah untuk mengetahui apakah semua komponen utama dari game telah mampu memberikan user experience seperti yang diharapkan sekaligus juga untuk 
mendeteksi adanya masalah teknis yang belum terdeteksi pada tahapan sebelumnya.

7) Rilis

Pada tahap ini game sudah siap untuk dirilis dan diperkenalkan pada target pemainnya. Ketika sebuah game telah dirilis untuk publik bukan berarti proses pengembangan selesai, mereka umumnya terus dioptimalkan/diupdate. Hal ini untuk memastikan bahwa game yang dihadirkan benar-benar mampu memberikan pengalaman bermain yang maksimal.

\section{Metode Penelitian}

Dalam penulisan paper ini, penulis menggunakan jenis penelitian library research, dimana permasalahan digambarkan dengan didasari pada data-data yang terdapat dalam literatur atau dokumen. Kemudian dianalisis lebih lanjut untuk diambil suatu kesimpulan. Menggunakan data sekunder, yaitu data yang bersumber dari studi kepustakaan.

Dalam pengumpulan data, penulis menggunakan teknik studi dokumentasi. Yaitu mengumpulkan data berdasarkan data-data yang berkaitan dengan masalah penulisan. Dalam menganalisi data, penulis menggunakan metode kualitatif yang bersifat deskriptif, di mana data atau informasi digambarkan berdasarkan fakta- fakta yang diperoleh.

\section{Konsep Teori Investasi Pasar Modal Pada Fun Boss Games (FBGs)}

Sebagai generasi milenial, masyarakat Indonesia mulai berubah pola berfikir dan mempengaruhi pola konsumsinya. Termasuk dalam memahami dan mempelajari hal-hal baru dalam kehidupan. Masyarakat cenderung menyukai cara-cara instan dan mudah dipahami. Model pendidikan dan literasi tradisional melalui halaqah atau didalam kelas kurang menarik rasa keingintahuanya. Sehingga generasi masyarakat sering pasif terhadap ilmu-ilmu baru, meskipun ilmu tersebut dianggap penting.

Sebagaimana dengan publikasi APJII (2016) menyatakan bahwa jumlah pengguna internet di Indonesia sebanyak 86,3 juta atau 65\% dari seluruh masyarakatnya. Dari jumlah tersebut, menurut SuperData, persentase konsumen game mobile yang membayar di Indonesia hampir lima puluh persen lebih tinggi dibandingkan India, dan cenderung membeli hampir dua kali lipat lebih banyak daripada konsumen normal (Tachinasia: 2017). Hal ini sesuai dengan prediksi Badan Ekonomi Kreatif Indonesia, sebagaimana dikutip dalam Techinasia (2017) yang menyatakan bahwa nilai pasar games di Indonesia mengalami peningkatan yang sangat pesat setiap tahunnya, hingga menembus angka US\$ 700 juta (sekitar Rp 9,3 triliun) dan akan kembali meningkat di tahun 2017.

Banyak stigma negative dalam penggunaan game terutama oleh beberapa kalangan masyarakat atas menjamurnya konsumsi game saat ini. Namun pada dasarnya tidak seluruh game dapat dinyatakan negative, bahkan beberapa game edukasi telah banyak ditemui. Sebagaimana dengan pembuktian Massachutes Insitute of Technology (MIT) bahwa game justru sangat berguna untuk meningkatkan logika dan pemahaman pemain terhadap suatu masalah melalui proyek game yang dinamakan dengan scratch (Vitianingsih, 2016: 1). Dengan demikian game dapat dinyatakan dapat menunjang pendidikan maupun literasi sesuai dengan masalah-masalah nyata yang disajikan dalam dimensi game.

Oleh sebab itu, penulis menawarkan konsep Fun Boss Games (FBGs) yang terinspirasi sebagai games literasi pasar modal syariah untuk para generasi milenial. FBGs merupakan game edukasi yang memberikan simulasi bagi para user melalui tantangan berpikir masyarakat sebagai 
investor atas masalah yang terdapat pada pasar modal yang berorientasikan pada keputusan penggunaan produk pasar modal syariah. Adapun tahapan tersebut meliputi net investor, less investor, sufle investor, dan well investor. Masing-masing tahapan tersebut akan dipaparkan dalam sub bab berikutnya. Adapun konsep pengimplementasian FBGs ialah sebagai berikut:

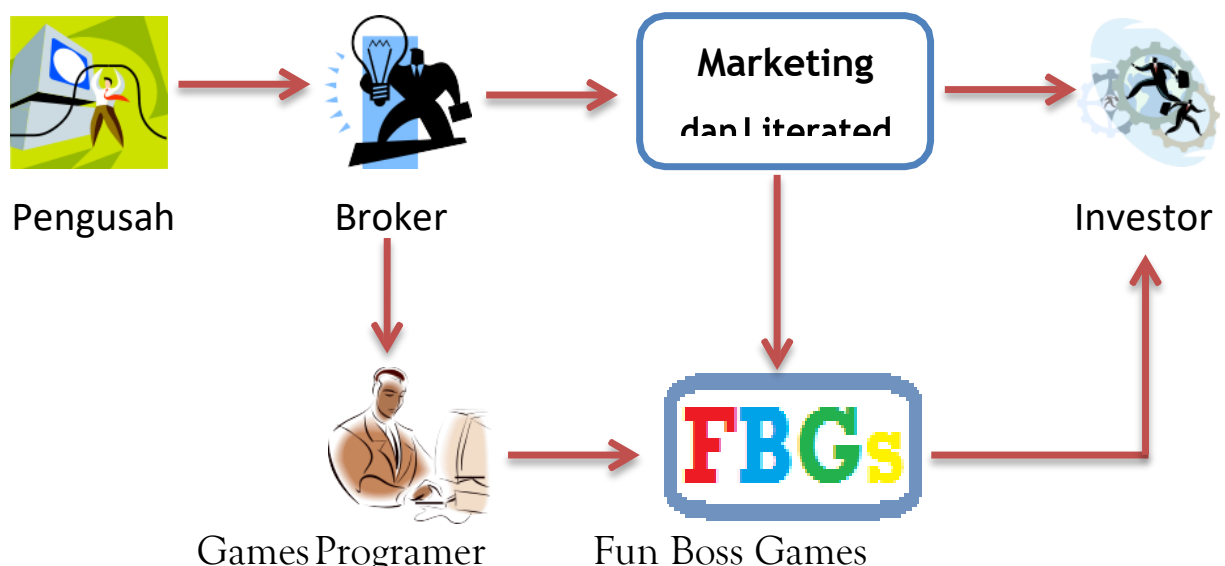

Sumber: Ilustrasi penulis.

Gambar 1 Ilustrasi Implementasi Fun Boss Games (FBGs)

Berdasarkan pada ilustrasi di atas, pengusaha atau pemilik usaha sebagai objek investasi pasar modal bekerja sama dengan Broker pasar modal sesuai dengan jenis surat berharga yang akan diterbitkan pengusaha untuk ditawarkan kepada investor. Broker bersama dengan Games Programer bekerjasama untukmenciptakan FBGs. FBGs yang merupakan game edukasi pasar modal tersebut menyajikan masalah dan tantangan investor sebagai wujud simulasi dalam berinvestasi. Sehingga investor sebagai user atau pengguna FBGs mudah memahami dalam pemilihan jenis investasi beserta pemecahan masalah kegiatan investasi.

\section{Tampilan Fun Boss Games (FBGs)}

Adapun teknis pemasaran games ini dilakukan oleh Broker sebagai media marketing atas produk pasar modalnya kepada calon investor dan Otoritas Jasa Keuangan (OJK) sebagai bentuk dukungan dari regulator pengawas lembaga keuangan. Pemasaran FBGs dilakukan pada play store sehingga mudah didapatkan oleh para masyarakat sebagai sasaran literasi investasi pasar modal syariah.
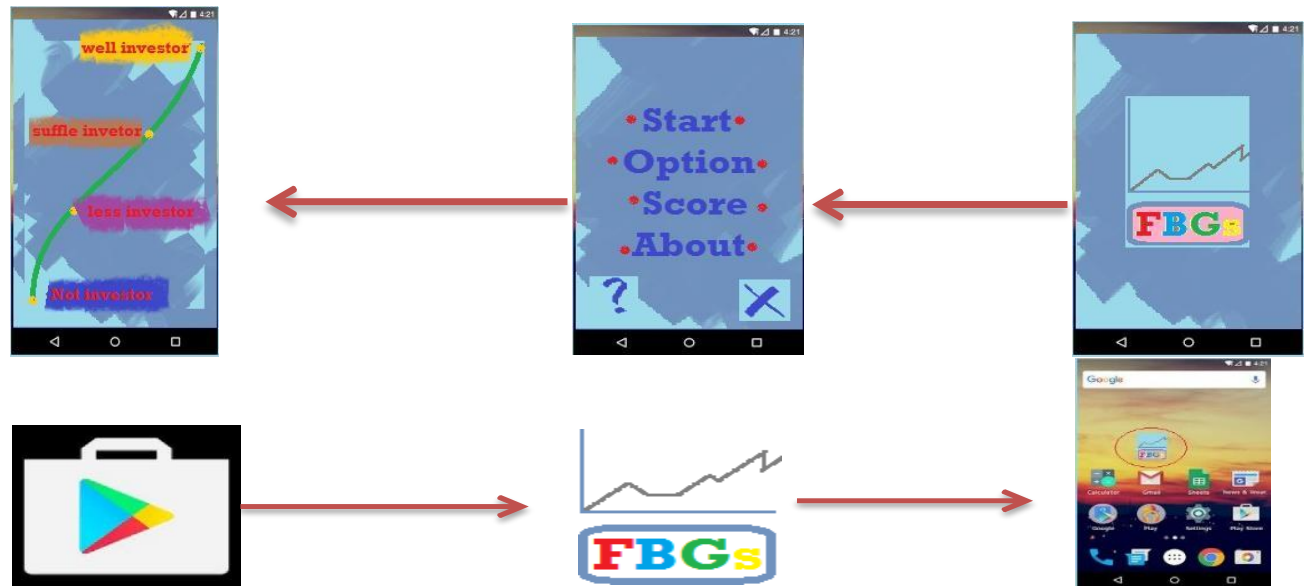
Gambar 2 Mekanisme Literasi Pasar Modal Syariah Kepada Calon Investor

Sesuai dengan ilustrasi di atas, FBGs dapat diunduh oleh masyarakat melalui aplikasi play store pada smartphone maupun personal computer. Setelah berhasil diunduh, maka surcut game FBGs secara otomatis keluar pada desktop smartphone maupun personal computer dan langsung dapat digunakan. Pada menu start diartikan bahwa game dimulai pada level pertama dan secara bertahap level dapat meningkat setelah berhasil menjawab level pertama dan seterusnya. Adapun urutan kelompok level dari level terendah hingga level tertinggi adalah well investor, sufle investor, less investor, dan net investor.

Adapun pada menu option mengatur mengenai tampilan, music, dan getaran yang menyesuaikan ekspresi atas penyelesaian tantangan game sesuai dengan benar atau salahnya penyelesaian masalah. Score memuat histori point atau score yang diperoleh user atau pemain game terakir penggunaan game tersebut. Sedangkan about berisikan prosedur pengaplikasian FBGs dan keterangan pada masing-masing symbol pada FBGs. Dalam tampilan menu tersebut disediakan tombol help sebagai petunjuk pemakaian setiap symbol menu dan simbol tanda silang yang bermakna untuk mengakhiri permainan.

\section{Hasil Dan Pembahasan}

\section{Fun Boss Games (FBGs) Sebagai Literasi Investasi Syariah}

Pada dasarnya FBGs ini ditujukan untuk memberikan pemahaman para masyarakat mengenai investasi pada pasar modal syariah. Dalam tahapan awal games ini memastikan bahwa pemikiran user berorientasi untuk melakukan investasi, memilih investasi jenis pasar modal, dan memilih investasi pasar modal syariah. Ketiga tersebut disajikan dalam berbagai tahapan, dimana pada tahapan awal user diberikan sejumlah modal dimana user ditantang untuk menggunakan modal tersebut.

Dalam level pengenalan, user diberikan simulasi pemilihan modal untuk membagi atas keperluan konsumsi dan investasi. Dalam hal ini user ditantang dalam pembagian modal tersebut pada keperluan konsumsi atau investasi, ketika memilih konsumsi semua maka dalam jangka waktu tertentu user akan kehabisan modal dan gagal. Sehingga user diberikan tantangan hingga menyelesaikan tantangan tersebut dengan pembagian angka yang tepat untuk keperluan konsumsi dan investasi.

Selanjutnya user diberikan simulasi dalam investasi pasar uang atau investasi pasar modal. Hal ini menyesuaikan pada jumlah modal dan perhitungan future value atau nilai investasi beserta jumlah keuntungan investasi dalam masa yang akan datang. Pada level tersebut user akan diberikan tantangan bahwa yang dimaksud dengan masa yang akan datang berorientasi pada dunia atau akhirat. Sehingga mennyajikan pilihan dalam penggunaan pasar modal konvensional atau pasar modal syariah. Dengan demikian user FBGs memahami perbedaan investasi syariah dan konvensional. Dimana investasi syariah berorientasi pada keuntungan dunia dan akhirat, sedangkan investasi konvensional berorientasikan pada keuntungan dunia saja.

\section{Tahapan Teknis Fun Boss Games (FBGs)}

Setelah user berhasil menyelesaikan tahap pengenalan dasar mengenai investasi pada pasar 
modal syariah, maka user dihadapkan dengan simulasi sebagai investor dalam empat kelompok tingkatan level. Adapun keempat tingkatan kelompok level secara berurutan dari tahap awal hingga akhir meliputi net investor, less investor, sufle investor, dan well investor. Keempat kelompok

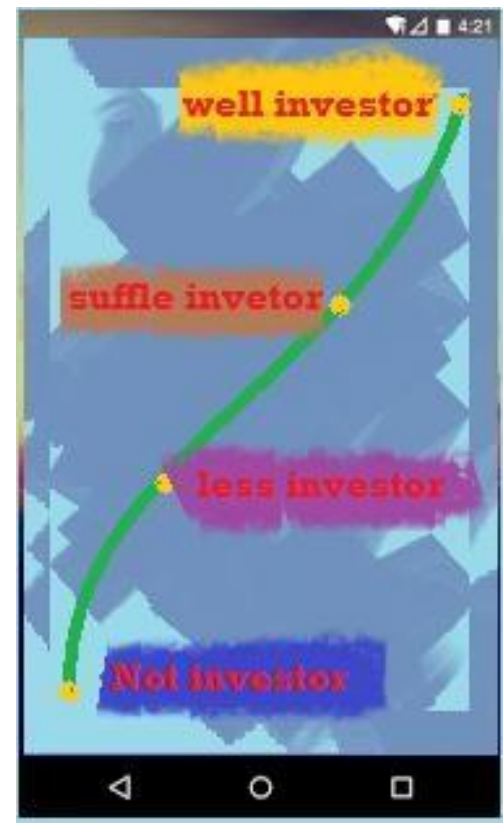

level tersebut disesuaikan dengan pemahaman user sebagai investor pasar modal syariah.

Gambar 3 Tahapan Kelompok Level Fun Boss Games (FBGs)

Dalam kelompok pertama pada FBGs, posisi user berada dalam level net investor. Kelompok level net investor berisikan simulasi tantangan untuk para user agar mengetahui investasi pasar modal syariah. dalam level tersebut user diuji atas keputusanya untuk menjadi investor dengan basik pemikirannya yang not literate atau sama sekali tidak mengetahui teknis investasi.

Setelah mengetahui teknis dasar investasi, maka user dapat naik pada kelompok level selanjutnya yakni less investor. Pemahaman user mengenai investasi telah melampaui dasarnya segigga posisi pemikiranya mengenai investasi sebagai investor less literate. Dalam tahap ini user diuji keputusanya sebagai investor yang dihadapkan dengan masalah investasi yang lebih ekstrim. User akan dihadapkan dengan produk-roduk investasi dengan pola yang bermacam-macam baik pola investasi stasioner hingga tidak stasioner hingga user benar-benar memahami teknis investasi secara advance.

Kemudian investor dihadapkan pada level kelompok suffle investor yakni pada pemahaman investasi tingkat suffle literate. Pemahaman investasi tingkat ini merupakan pola pemikiran user benar-benar mengetahui teknis dasar dan yakin berinvestasi dengan dihadapkan dalam segala bentuk produk investasi serta dalam kategori yakin. Dalam kategori yakin ini, user dihadapkan dengan timer pengambilan keputusan. Dalam seting waktu tertentu user dianggap lolos pada kelompok level tersebut.

Terakhir level kelompok well investor, dimana dalam tingkatan level ini user benar-benar harus mencapai kelas terampil atau advance berinvestasi dengan kategori well literate. Dalam kelompok ini user dihadapkan dengan segala jenis produk, masalah, dan jangka waktu yang sangat cepat dalam pengambilan keputusan investasi. Sehingga setelah mencapai pada level terakir pada 
kelompok ini investor dinyatakan terampil berinvestasi dan dapat melakukan investasi pada pasar modal syariah dalam investasi yang sesungguhmya.

\section{Kontribusi Akhir Fun Boss Games (FBGs)}

Keberadaan FBGs ini dapat dijadikan fasilitas bagi masyarakat umum untuk mengetahui, memahami, hingga terampil dalam melakukan investasi pada pasar modal syariah. dengan demikian program literasi keuangan pasar modal dapat disajikan dalam bentuk yang lebih menarik, efektif, dan efisien. Sajian literasi dalam benttuk game ini sesuai dengan sasaran investasi pada masa usia produktif, sehingga ketika produktifitas seseorang tinggi maka investasi yang harus dikeluarkan berbanding positif. Dengan demikian dalam jangka waktu tertentu ketika produktifitas menurun, dapat diimbangi dengan hasi investasi pada masa yang akan datang tersebut.

Selain itu, game ini juga mampu menggugurkan stigma masyarakat akan dampak negative suatu game edukasi. Hal ini dilihat dari multiplier effect atau FBGs berupa pemahaman investasi pada usia produktif, sehingga meningkatkan investasi. Ketika jumlah investasi meningkat, maka jumlah modal produksi juga meningkat. Hal ini akan meningkatkan produktivitas perusahaan baik secara kualitas maupun kuantitasnya. Sehingga perputaran uang semakin cepat dan meningkatkan keuntungan.

Seiring dengan jangka waktu investasi, investor akan mendapat keuntungan atau margin atas investasinya. Dengan demikian pendapatan investor turut meningkat. Jika sudah memenuhi batas tertentu, maka investor dapat menambah nilai investasinya atas pendapatan yang diperoleh. Sehingga dampak atas investasi tersebut kembali berputar dan mengutungkan seluruh pihak yang terlibat atas investasi maupun bagi yang tidak terlibat dalam investasi tersebut. Hal ini dikarenakan secara eksternal ketika produktifitas meningkat, maka pertumbuhan ekonomi negara juga akan turut meningkat.

\section{Kesimpulan}

Berdasarkan pembahasan di atas, maka dapat disimpulkan konsep teori investasi pada pasar modal dapat diterapkan pada Fun Boss Games (FBGs) sebagai games literasi pasar modal syariah untuk para generasi milenial, sebagai game edukasi yang memberikan simulasi bagi para user melalui tantangan berpikir masyarakat sebagai investor atas masalah yang terdapat pada pasar modal yang berorientasikan pada keputusan penggunaan produk pasar modal syariah.

Teknis pemasaran games ini dilakukan oleh Broker sebagai media marketing atas produk pasar modalnya kepada calon investor dan Otoritas Jasa Keuangan (OJK) sebagai bentuk dukungan dari regulator pengawas lembaga keuangan melaui play store sehingga mudah didapatkan oleh para masyarakat sebagai sasaran literasi investasi pasar modal syariah.

Fun Boss Games (FBGs) ditujukan untuk memberikan pemahaman para masyarakat mengenai investasi pada pasar modal syariah melaui tahapan awal games ini memastikan bahwa pemikiran user berorientasi untuk melakukan investasi, memilih investasi jenis pasar modal, dan memilih investasi pasar modal syariah.

\section{Daftar Pustaka}

Adams, Ernest. 2010. Fundamentals of Game Design. USA : Education. 
Asosiasi Penyelenggara Jasa Internet Indonesia (APJII). Saatnya Jadi Pokok Perhatian Pemerintah dan Industri. Buletin , edisi 05. Jakarta: November 2016.

Aziz, Abdul, 2010. Manajemen Investasi Syari'ah. Bandung: Alfabeta.

Jusmaliani, 2008. Investasi Syari'ah. Jakarta: Kreasi Wacana.

Pakpahan, Kadiman. 2013. Strategi Investasi di Pasar Modal. Journal The Winners Vol. 4 Nom. September 2003.

Soemitra, Andri, 2009. Bank dan lembaga keuangan syariah. Jakarta: Kencana.

Sutedi, Adrian, 2011. Pasar Modal Syariah. Jakarta: sinau grafika.

Vitianingsih, Anik Vega. Game Edukasi Sebagai Media Pembelajaran Pendidikan Anak Usia DIni. Jurnal INFORM, Vol. 1, No. 1, ISSN: 2502-3470. 20

Hidayat, Wicak. 2013. Tahapan Pengembangan game. Internet http://tekno.kompas.com/read/2013/08/21265087.tahap.pengembangan.game. diakses pada 20 Oktober 2017.

Maulana, Risky. Tingkat Perkembangan Pasar Game Mobile Indonesia Tiga Kali Lipat Amerika Serikat. Techinasia: Februari, 2017. Di akses pada: https://id.techinasia.com/perkembangan-pasar-gameindonesia-salahsatu-yang-tertinggi-di-2016. 